M. Porceddu, S. Barros Torres \& G. Bacchetta

\title{
Seed germination reports for Teucrium massiliense and T. flavum subsp. glaucum (Lamiaceae)
}

\begin{abstract}
Porceddu, M., Barros Torres, S. \& Bacchetta, G.: Seed germination reports for Teucrium massiliense and T. flavum subsp. glaucum (Lamiaceae) [In Magrini, S. \& Salmeri, C. (eds), Mediterranean plant germination reports - 3]. Fl. Medit. 31: 264266. 2021. http://dx.doi.org/10.7320/FlMedit31.264
\end{abstract}

The present work gathers new germination assays of two Teucrium species from Sardinia. The studied taxa are: Teucrium massiliense and T. flavum subsp. glaucum. Seeds were collected at the time of natural seed dispersal in two different localities of Sardinia (Italy). The germination tests were carried out at the Sardinian Germplasm Bank (BG-SAR). Our results showed a high germination capability and germination rate for the tested plant species.

Key words: Lamiaceae, Mediterranean species, Sardinia.

The genus Teucrium L. includes ca. 300 taxa belonging to the Lamiaceae family; their distribution is mainly concentrated in the Mediterranean region (Navarro \& El Oualidi 2000). Many taxa of the genus Teucrium have been used in traditional medicine. Regarding the species studied for this report, T. massiliense L. has been used as antimalarial, febrifuge, and cicatrizing, while T. flavum subsp. glaucum (Jord. \& Fourr.) Ronniger as cicatrizing, antiseptic, febrifuge, antirheumatic, and to treat sciatica and dislocation (Maccioni \& al. 2021). Given the indisputable importance of these two species, understanding the reproductive mechanisms and indicating the best conditions for seed germination of these taxa are fundamental.

This work illustrated new germination data of these two Teucrium species collected in two different localities of Sardinia (Italy). The germination tests were carried out at the Sardinian Germplasm Bank (BG-SAR; Porceddu \& al. 2017). Our results showed a high germination capability and germination rate for the tested plant species.

\section{Teucrium massiliense L. (Lamiaceae)}

\section{Accession data}

Sa: Gonnosfanadiga (Sud Sardegna), Foresta Demaniale Montimannu (WGS84: $\left.39.443036^{\circ} \mathrm{N}, 8.648336^{\circ} \mathrm{E}\right)$, garrigue, $1022 \mathrm{~m}$ a.s.1., 03 Aug 2018, M. Porceddu, 
G. Bacchetta, G. Calvia \& S. Fantini (BG-SAR-2018-24, Sardinian Germplasm Bank).

\section{Germination data}

Pre-treatments: no treatment.

Germination medium: 1\% agar.

Sample size: 100 seeds $(25 \times 4$ replicates $)$.

\begin{tabular}{ccccccc}
\hline Germination & Thermoperiod & $\begin{array}{c}\text { Photoperiod } \\
{[\text { light/dark] }}\end{array}$ & T $_{\mathbf{1}}[\mathbf{d}]$ & $\mathbf{T}_{\mathbf{5 0}}[\mathbf{d}]$ & $\mathbf{T}_{\mathbf{m a x}}[\mathbf{d}]$ & MTG [d] \\
\hline $\mathbf{8 4 . 0} \%$ & constant $10^{\circ} \mathrm{C}$ & $12 / 12 \mathrm{~h}$ & 13.0 & 14.6 & 44.0 & 17.0 \\
\hline $\mathbf{8 0 . 0} \%$ & constant $15^{\circ} \mathrm{C}$ & $12 / 12 \mathrm{~h}$ & 9.0 & 9.3 & 36.0 & 11.7 \\
\hline $\mathbf{8 0 . 0} \%$ & constant $20^{\circ} \mathrm{C}$ & $12 / 12 \mathrm{~h}$ & 6.0 & 7.0 & 15.0 & 8.5 \\
\hline $\mathbf{9 0 . 0} \%$ & constant $25^{\circ} \mathrm{C}$ & $12 / 12 \mathrm{~h}$ & 6.0 & 8.8 & 36.0 & 12.5 \\
\hline $\mathbf{8 7 . 0} \%$ & alternating $25 / 10^{\circ} \mathrm{C}$ & $12 / 12 \mathrm{~h}$ & 10.0 & 11.3 & 28.0 & 13.2 \\
\hline
\end{tabular}

\section{Observations}

Teucrium massiliense is an evergreen small shrub with grey-green leaves and rose-pink flowers that blooms from July to September. It grows wild in some areas of the Mediterranean basin, particularly in Sardinia and Corsica.

Seeds of T. massiliense germinated in a wide range of temperatures, from $10^{\circ} \mathrm{C}$ to $25^{\circ} \mathrm{C}$; in addition, high germination percentage was also detected at alternating temperature $25 / 10^{\circ} \mathrm{C}$. Low germination (ca. $30 \%$ ) was detected at $5^{\circ} \mathrm{C}$. Very few germination data are present in the literature for this species. The results obtained by BG-SAR for T. massiliense from Sardinia showed faster germination than rates reported in the RBG Kew's Seed Information Database (Royal Botanic Gardens Kew, 2021) for the same species.

47. Teucrium flavum subsp. glaucum (Jord. \& Fourr.) Ronniger (Lamiaceae)

\section{Accession data}

Sa: $\quad$ San Vito (Sud Sardegna), loc. Bacu Is Angius (WGS84: $39.338719^{\circ} \mathrm{N}, 9^{2} 466844^{\circ} \mathrm{E}$ ), garrigue and shrubs, $145 \mathrm{~m}$ a.s.1., 08 Aug 2018, G. Bacchetta \& G. Calvia (BGSAR-2018-37, Sardinian Germplasm Bank).

\section{Germination data}

Pre-treatments: no treatment.

Germination medium: 1\% agar.

Sample size: 80 seeds $(20 \times 4$ replicates $)$. 


\begin{tabular}{ccccccc}
\hline Germination & Thermoperiod & $\begin{array}{c}\text { Photoperiod } \\
{[\text { light/dark] }}\end{array}$ & $\mathbf{T}_{\mathbf{1}}[\mathbf{d}]$ & $\mathbf{T}_{\mathbf{5 0}}[\mathbf{d}]$ & $\mathbf{T}_{\max }[\mathbf{d}]$ & MTG [d] \\
\hline $\mathbf{8 6 . 3 \%}$ & constant $15^{\circ} \mathrm{C}$ & $12 / 12 \mathrm{~h}$ & 7.0 & 9.5 & 16.0 & 11.3 \\
\hline $\mathbf{8 1 . 3 \%}$ & constant $20^{\circ} \mathrm{C}$ & $12 / 12 \mathrm{~h}$ & 7.0 & 10.4 & 37.0 & 12.8 \\
\hline
\end{tabular}

\section{Observations}

Teucrium flavum subsp. glaucum is an evergreen small shrub with green leaves and white flowers that blooms from May to July. It grows spontaneously in Sardinia, Calabria, Basilicata (Bartolucci \& al. 2018), and in Corsica (Jeanmonod \& Gamisans 2007). Seeds of T. flavum subsp. glaucum reached high germination percentages at 15 and $20^{\circ} \mathrm{C}$. Germination of $49 \%$, $45 \%$ and $71 \%$ were recorded at 10,25 and $25 / 10^{\circ} \mathrm{C}$, respectively, while no germination was observed at $5^{\circ} \mathrm{C}$. Very few germination data are present in the literature for this species. The results obtained by BG-SAR for T. flavum subsp. glaucum from Sardinia are consistent with those reported by the RBG Kew's Seed Information Database (Royal Botanic Gardens Kew, 2021) for the same taxon, however, the seeds tested by BG-SAR showed faster germination, reaching the $\mathrm{T}_{50}$ values within 11 days both at 15 and $20^{\circ} \mathrm{C}$.

\section{References}

Bartolucci, F., Peruzzi, L., Galasso, G., Albano, A., Alessandrini, A., Ardenghi, N. M. G., Astuti, G., Bacchetta, G., Ballelli, S., Banfi, E. \& al. 2018: An updated checklist of the vascular flora native to Italy. - Pl. Biosyst. 152: 179-303. https://doi.org/10.1080/11263504.2017.1419996

Jeanmonod, D. \& Gamisans, J. 2007: Flora Corsica. - Aix-en-Provence.

Maccioni, A., Falconieri, D., Sanna, C., Porcedda, S., Piras, A. \& Maxia, A. 2021: Characterization of Essential Oils from Different Taxa Belonging to the Genus Teucrium in Sardinia Island, Italy. - Plants 10: 1359. https://doi.org/10.3390/plants10071359

Navarro, T., \& El Oualidi, J. 2000: Synopsis of Teucrium L. (Labiatae) in the Mediterranean region and surrounding areas. - Fl. Medit. 10: 349-363.

Porceddu, M., Santo, A., Orrù, M., Meloni, F., Ucchesu, M., Picciau, R., Sarigu, M., Cuena Lombraña, A., Podda, L., Sau, S., Fogu, M. C. \& Bacchetta, G. 2017: Seed conservation actions for the preservation of plant diversity: the case of the Sardinian Germplasm Bank (BGSAR). - Pl. Sociol. 54(2): 111-117. https://doi.org/10.7338/pls2017542S1/11

Royal Botanic Gardens Kew 2021: Seed Information Database (SID). Version 7.1. http://data.kew.org/sid/ [Last accessed 07/10/2021]

Addresses of the authors:

Marco Porceddu ${ }^{1,2 *}$, Salvador Barros Torres ${ }^{3} \&$ Gianluigi Bacchetta ${ }^{1,2}$,

${ }^{1}$ Sardinian Germplasm Bank (BG-SAR), Hortus Botanicus Karalitanus (HBK),

University of Cagliari, Sardinia, Italy. E-mails: porceddu.marco@unica.it; bacchet@unica.it

${ }^{2}$ Department of Life and Environmental Sciences, Centre for the Conservation of Biodiversity (CCB), University of Cagliari, Sardinia, Italy.

${ }^{3}$ Universidade Federal Rural do Semi-Árido/Departamento de Ciências Agronômicas

e Florestais, Mossoró, RN, Brazil. E-mail: sbtorres@ufersa.edu.br

* Corresponding author 